\title{
МЕХАНІЗМ ТРАНСФОРМАЦІї ІНТЕРЕСІВ В ЕКОЛОГО-ПРАВОВОМУ КОНФЛІКТІ
}

Яремак 3. В.

У науковій статmі здійснено теоретико-правове дослідження інтересу в механізмі еколого-правового конфлікту. Проаналізовано теоретичні розробки проблем правового інтересу та екологічного інтересу. Одержані результати екстрапольовано у площину еколого-правового конфлікту й доведено, що правова природа інтересів у механізмі еколого-правового конфлікту є різною: на початковому етапі виникнення конфлікту інтерес $є$ об'єктивною категорією; оскільки конфлікт є соціальним протиріччям, то інтерес набуває ознак суб'єктивного характеру; у процесі узгодження інтересів сторін конфлікту інтерес отримує правове опосередкування через суб'єктивні права та законні інтереси.

Ключові слова: правовий інтерес, законний інтерес, суб'єктивне право, екологічний інтерес, екологоправовий конфлікт.

В научной статье проведено теоретико-правовое исследование интереса в механизме эколого-правового конфликта. Проанализированы теоретические разработки проблем правового интереса и экологического интереса. Полученные результаты экстраполированы в плоскость эколого-правового конфликта и доказано, что правовая природа интересов в механизме эколого-правового конфликта различна: на начальном этапе возникновения конфликта интерес является объективной категорией; так как конфликт является социальным противоречием, то интерес приобретает признаки субъективного характера; в процессе согласования интересов сторон конфликта интерес трансформируется в субъективные права и законные интересы.

Ключевые слова: правовой интерес, законный интерес, субъективное право, экологический интерес, эколого-правовой конфликт.

Yaremak Z. V. The mechanism of interest transformation in the environmental law conflict

The article carries out a theoretical and legal study of interest in the mechanism of environmental law conflict. To this end, the theoretical development of legal interest problems as a basic (generic) category in relation to interest in environmental law is analyzed. The conclusions about the ambiguity of scientific approaches to understanding the essential characteristics of legal interest are drawn. An objective phenomenon, as a subjective category and dialectical connection of objective and subjective is considered.

In the course of further research to determine the content of environmental interest as a fundamental category of environmental law, it is substantiated, that the ambiguity of approaches to understanding the essence of legal interest has been continued in environmental law. Based on the scientific positions analysis, it is concluded that two scientific concepts on the substantive characteristics of environmental interest are formed in general:

1) environmental interest as a basis for environmental and legal relations, reflecting and ensuring the need for ecologically safe human environment;

2) ecological interest is considered in the context of the ecological and legal status of a person and is correlated with subjective environmental law.

The obtained results are environmental law conflict extrapolated and the substantive characteristics of interest are determined. It is convincingly proved that the legal nature of interests in the mechanism of environmental law conflict are different: at the initial stage of the conflict the interest is an objective category and form of expression of ecologically safe environmental needs. Since the ecological and legal conflict is a social contradiction, the unsub of social interaction must realize the interest, and thus it acquires signs of a subjective nature. Finally, in the process of reconciling the interests of the parties, the interest acquires legal mediation through environmental rights and legitimate interests, which act as independent objects of protection. This approach enables to coordinate and "reconcile" existing scientific concepts of both interests: legal interest and interest in environmental law.

Key words: legal interest, legitimate interest, subjective law, ecological interest, environmental law conflict.

Постановка проблеми та їі актуальність. Функціонування сучасного суспільства визначається багатьма чинниками, серед яких вагоме місце посідає соціальний інтерес. Різноманіття соціальних інтересів зумовлюють конфліктний характер взаємовідносин між людьми в їх соціально-політичних, економічних та інших сферах. Надзвичайно конфліктною була та залишається сфера взаємодії суспільства із природою: ширше залучення природних ресурсів у виробництво сприяє

(c) Яремак 3. В., 2020 
зростанню економіки, однак призводить до руйнування природного середовища існування людини. Тому будь-яка форма природокористування внутрішньо суперечлива: «<...> зростання економіки неминуче супроводжується зростанням кількості вилучених природних ресурсів із природного середовища, що викликає значне погіршення його стану» [1, с. 308]. За цих умов важливого значення як у теоретичному, так і практичному аспектах набуває проблема оптимального взаємозв'язку між економічною та екологічною формами використання природних ресурсів, між задоволенням потреб суспільства та збереженням довкілля.

Аналіз останніх досліджень і публікацій. Категорія «інтерес» досить часто $€$ предметом наукових публікацій, що зумовлено міждисциплінарним характером цього терміна та досліджується представниками різних галузей знань: соціології, екології, соціальної екології, філософії, психології тощо. Визначення інтересу як правової категорії закладено науковцями в галузі теорії права: С.В. Бобровник, Я.І. Ленгер, М.А. Самбор, А.А. Соколова, С.В. Солдатенко, а вже особливості інтересу, механізм нормативного закріплення в екологічному праві та реалізації у правозастосовній діяльності $є$ предметом дослідження еколого-правової науки: Г.В. Анісімова, Г.І. Балюк, Н.Р. Кобецька, А.І. Мірошниченко, Г.В. Мороз, В.В. Петров та інші. Водночас сфера дії екологічного права $є$ найбільш конфліктною, а питання оптимізації та узгодження різнопланових інтересів, які лежать в основі виникнення, розвитку та існування еколого-правових конфліктів, не втрачає актуальності.

Метою статті $\epsilon$ з'ясування ролі та місця інтересу в механізмі еколого-правового конфлікту, а також його модифікацію у процесі виникнення, розвитку та врегулювання еколого-правового конфлікту.

Виклад основного матеріалу. У преамбулі Закону України «Про охорону природного довкілля» [2] йдеться про інтереси нинішнього й майбутніх поколінь; у ст. 3 серед принципів екологічної політики визначено i принцип науково обґрунтованого узгодження екологічних, економічних та соціальних інтересів суспільства; у ст. 12 зобов'язано громадян не порушувати екологічні права та законні інтереси інших суб'єктів. У Законі України «Про основні засади (стратегію) державної екологічної політики України на період до 2030 року» [3] згадується про гармонійне поєднання загальнонаціональних і регіональних інтересів. Як бачимо, навіть такий поверхневий аналіз указує на те, що екологічне законодавство оперує терміном «інтерес» для позначення зацікавленості як усього суспільства, так і окремих суб'єктів, визначаючи різноплановий характер цих інтересів, не розкриваючи його змісту та функціонального значення. Тому питання інтересу в екологічному праві $\epsilon$ предметом гострої наукової дискусії.

Теоретичні розробки проблем інтересу в екологічному праві варто розпочати з аналізу правового інтересу як базової (родової) категорії щодо інтересу в екологічному праві. У науковій літературі наводяться протилежні за змістом теорії щодо розуміння правової природи інтересу. Так, М.А. Самбор у межах свого дисертаційного дослідження пропонує розглядати інтерес у праві як усвідомлену спрямованість суб'єкта, зумовлену його внутрішнім переконанням в оволодінні певним благом матеріального чи нематеріального характеру, що $є$ задоволенням потреби, здійснення та реалізація якого відбувається в межах загальноприйнятих правил поведінки, визначених у нормах права, що відповідає відсутності прямої заборони в досягненні такого блага, так і бажаним для нього способом, а також спирання на забезпечення компетентними органами в разі наявності перешкоди на шляху можливості його задоволення [4, с. 7]. Загальнотеоретичне поняття правової категорії «правовий інтерес» виведено С.В. Солдатенко як формально визначеної та гарантованої державою необхідності суб'єктів права, передбаченими законом засобами та способами обирати модель своєї суспільної поведінки задля задоволення власних потреб i досягнення цілей, яка реалізується ними у формі правових відносин [5, с. 11]. Категорично заперечує суб'єктивний фактор інтересу В.К. Попов та наполягає, що інтерес потрібно розглядати виключно як об'єктивне явище, що зумовлене самою природою й соціальними умовами життя людей [6, с. 11]. Д.О. Гетьманцев змінив вектор дослідження, наділяючи «інтерес» різними значеннями, а саме:

1) критерій розмежування публічного та приватного права;

2) спонукання до реалізації суб'єктивного права;

3) певного «блага», «користі» [7, с. 82].

Підбиваючи підсумки поданої наукової дискусії, можемо виокремити такі основні концепції інтересу, як правової категорії:

1) як об'єктивне явище (змістом інтересу $\epsilon$ об'єктивні потреби, які зумовлені умовами суспільного буття); 


\section{Проблеми екологічного законодавства}

2) як суб'єктивна категорія (про інтерес можна говорити виключно в тому разі, коли $\epsilon$ усвідомлення інтересу суб'єктом);

3) діалектичний зв' язок об'єктивного та суб' $є$ тивного.

Однією первинних проблематик дослідження інтересу в екологічному праві $\epsilon$ визначення змісту екологічного інтересу як фундаментальної категорії. Розвитку наукової дискусії сприяє нечіткість національного екологічного законодавства та відсутність легального визначення екологічного інтересу, на чому неодноразово наголошували вчені [8, с. $513-521$; 9, с. 12-13; 10, с. 11 ; 11, с. 98].

В еколого-правовій доктрині одним із перших визначив поняття екологічного інтересу та вказав на його об'єктивний характер В.В. Петров: «Екологічні інтереси - це об'єктивно існуючі потреби людини в чистому, здоровому, продуктивному природному довкіллі, що забезпечує біологічний режим життя. Існують у єдності та боротьбі протилежностейзекономічними інтересами» [12, с. 378]. В.С. Шахов наголошує на тому, що екологічні інтереси в суспільних правовідносинах полягають не тільки в охороні довкілля, а і в інтенсивному користуванні природними об'єктами для сталого економічного й соціального розвитку соціуму [13, с. 214]. Натомість Г.В. Мороз зауважує, що істинні екологічні інтереси відображають зміст безпосередніх екологічних потреб людини, які визначають характер і спрямованість інтересів. Коли ж ідеться про використання людиною суто споживчих, корисних властивостей природи без урахування їх вичерпності та без ужиття природоохоронних, профілактичних, відновлювальних заходів, первинний вигляд екологічних інтересів утрачає свою позитивну спрямованість, перетворюючись у безпосередньо економічні інтереси (чи інші види інтересів) [14, с. 206]. На думку А.І. Мірошниченка, екологічний інтерес $\epsilon$ сукупністю претензій учасників екологічних відносин, котрі дають підстави для їх соціального зв'язку в екологічному процесі й зумовлюють можливість здійснення екологічного інтересу завдяки реалізації їх юридичного статусу. Змістом екологічного інтересу $є$ : по-перше, збереження й відновлення природних систем, їх біологічного різноманіття і здатності до саморегуляції як необхідної умови існування людського суспільства; по-друге, забезпечення раціонального природокористування й рівноправного доступу до природних ресурсів; по-третє, забезпечення сприятливого стану довкілля як необхідної умови покращення якості життя і здоров'я населення [15, с. 7]. Суб'єктивного змісту екологічному інтересу надає I.I. Парфьонов, визначаючи екологічні інтереси як усвідомлену особою (суспільством) потребу в забезпеченні здорових і безпечних умов життєдіяльності, що сприятимуть повноцінному функціонуванню суспільства й держави [16, с. 119]. Синхронізувати та об'єднати суб'єктивні та об'єктивні фактори екологічного інтересу пропонує російська вчена M.І. Васильєва. На їі думку, з однієї сторони - екологічний інтерес, тобто інтерес у збереженні природних об'єктів, підтримці придатної для життя якості довкілля, умовно становить мотивуючу частину права на безпечне довкілля (об'єктивний аспект - 3. Я.), а з іншої екологічний інтерес - це своєрідна форма публічного вираження суб'єктивного права на безпечне довкілля, його соціально значима оцінка (суб'єктивний аспект - 3. Я.) [17, с. 60-61].

Узагальнюючи наукові напрацювання екологів-правників, робимо висновок, що в межах екологічного права точаться аналогічні дискусії щодо змістовних характеристик екологічного інтересу, як і щодо правового інтересу, визначаючи об'єктивний та суб'єктивний характер останнього. Такі наукові позиції знайшли своє відображення у двох основних концепціях:

1) екологічний інтерес як основа еколого-правових відносин, що відображає та забезпечує потребу в екологобезпечному середовищі існування людини;

2) екологічний інтерес розглядається в контексті еколого-правового статусу особи та співвідноситься із суб'єктивним екологічним правом.

Спробуємо екстраполювати одержані результати у площину еколого-правового конфлікту, визначивши суть та змістовні характеристики інтересу як одного з детермінантів цього виду конфлікту. В основі будь-якого конфлікту лежить соціальне протиріччя, яке зумовлено протилежністю або суттєвими відмінностями цілей, інтересів, потреб, цінностей тощо суб'єктів взаємодії. Як зауважує А.А. Соколова, модифікація потреб, як наслідок розвитку цивілізації, породжує дедалі ширший спектр інтересів індивіда в найрізноманітніших сферах його буття [18]. Звідси випливає неминучий конфлікт між протилежними інтересами: конфлікт - це зіткнення інтересів, потреб і спричиненої цим зіткненням боротьби сторін [19, с. 26-27; 20, с. 121].

Дослідження категорії інтересу під кутом зору еколого-правового конфлікту варто розглядати, перш за все, як соціальне явище, котре $\epsilon$ спону- 
кальним чинником виникнення конфлікту, передує йому, у зв'язку з чим можемо говорити, що інтерес знаходиться поза межами конфлікту. Із цих позицій підтримуємо думку Г.В. Анісімової, яка визначає екологічний інтерес як об'єктивно існуюче, особливого роду ставлення соціальних суб'єктів до екологічних потреб та інших умов життя, що забезпечують їм нормальну життєдіяльність та екологічну рівновагу у природному довкіллі [21, с. 15]. Інтерес як передумова виникнення еколого-правового конфлікту характеризується своєю подвійністю цілей: «між потребами господарської експлуатації, використання природних ресурсів як сировинної бази економіки й необхідності збереження та раціонального використання природних ресурсів (природноресурсовий (публічний чи приватний) та екологічний (публічний чи приватний) інтерес); між корпоративними господарськими інтересами природно добувних компаній у максимальній експлуатації природних благ та суспільними інтересами населення відповідної території у збереженні нормальних умов свого існування (приватний економічний та суспільний екологічний інтерес)» [22, с. 407]. Таким чином, суб'єкти, беручи участь в еколого-правових відносинах, реалізовують не тільки власне екологічні (природоохоронні) інтереси, але й низку інших інтересів - економічних, естетичних, культурних тощо. Звідси випливає, що еколого-правовий конфлікт базується на зіткненні екологічних та інших видів інтересів.

Водночас конфлікт зумовлений протистоянням, протиставленням інтересу одного суб'єкта інтересам іншого. А це означає, що особа повинна усвідомлювати власний інтерес, тобто інтерес набуває суб'єктивного характеру. У дослідженнях С.В. Бобровник, яку вважають одним із провідних фахівців вітчизняної юридичної конфліктології, на основі антрополого-комунікативного підходу до питань конфлікту останній трактується як «стан двостороннього зв'язку суб'єктів, заснований на правовому протиріччі, що характеризується порушенням або перешкодою в реалізації ними інтересів та слугує причиною розвитку або кризи суспільних відносин» [23, с. 6]. Я.І. Ленгер наголошує на тому, що конфлікт $\epsilon$ насамперед усвідомленим протиріччям, що полягає у протилежності сторін, що готові вжити певних заходів та дій [24, с. 59]. Підтримує таку позицію і вчений-цивіліст Ю.М. Жорнокуй, акцентуючи увагу на активній поведінці суб'єктів взаємодії: протиріччя і протилежності перетворюються на конфлікт лише тоді, коли починають діяти суб'єкти, які є їх носіями - порушувати або створювати загрозу порушення прав та/або інтересів інших учасників конкретного правового зв'язку. Водночас їх дії часто виходять із недостатньо продуманих правових механізмів, закладених у нормах права, прогалинах у праві або $\epsilon$ зловживанням правом [25, с. 56].

Трансформуючи таке бачення інтересу у площину еколого-правових конфліктів, робимо висновок про наявність у суб'єктів усвідомлених протилежних інтересів (екологічних та економічних передусім), які у процесі взаємодії, бувши учасниками еколого-правових відносин, зумовлюють виникнення конфлікту. Поза межами соціальної взаємодії особа задовольняє свою потребу, не спричиняючи конфлікт інтересів.

І останнє, суб'єкт, уступаючи в конфронтаційну взаємодію з іншим суб'єктом, має на меті реалізувати, а у разі неможливості - захистити свій інтерес. Використовуючи юридичні механізми врегулювання еколого-правового конфлікту, екологічний інтерес трансформується у дві правові форми - суб'єктивне право й законний інтерес (охоронюваний законом інтерес) - як самостійні об'єкти захисту. Не вдаючись в аналіз дискусії про співвідношення та визначення сутнісних характеристик понять «інтерес», «екологічний інтерес», «законний інтерес», «охоронюваний законом інтерес», проведемо розмежування категорій екологічного інтересу й суб'єктивних екологічних прав. Як справедливо зазначає Г.І. Балюк, вітчизняному законодавству притаманна нечіткість у використанні юридичної термінології «інтерес». Окрім термінологічної невизначеності, вчена вказує й на низку інших проблем: інколи неможливо зрозуміти, яке значення було вкладено законодавцем у термін «інтерес»; інколи інтереси просто ототожнюються із суб'єктивними правами, замінюючи один одного; буває й інша ситуація, коли інтереси й суб'єктивні права протиставляються один одному - законодавець використовує роздільний союз «право або інтереси» [9, с. 12-13].

В.А. Васильєва, проводячи розмежування між суб'єктивним правом та інтересом, зазначає наступне: «І суб'єктивне право, й інтерес $\epsilon$ дозволами. Але право $є$ дозволом, що відображений в об'єктивному праві, а інтерес відображається у формулі: «Дозволено все, що не заборонено законом». Інтерес, навіть перебуваючи під охороною закону чи права, на відміну від суб'єктивного права, не має гарантованої правової можливості» [26, с. 131]. Цілком погоджуючись із запропонованим твердженням, додамо, що відмінність суб'єктивного екологічного права від екологічного 


\section{Проблеми \\ екологічного законодавства}

інтересу полягає в тому, що екологічне право $\epsilon$ правовою гарантією, яка забезпечується відповідним обов'язком інших осіб, натомість екологічний інтерес - це лише дозвіл на певний вид поведінки за відсутності юридичних заборон. До того ж, як уважає М.І. Васильєва, немає принципово юридичних перешкод для того, щоб уважати законними не тільки ті групи інтересів, які прямо визначені законодавством, а й ті, які виявляються «за фактом» у конкретних еколого-правових відносинах, заявляються й відстоюються громадянами й водночас не суперечать нормам законодавства, загальним принципам правового регулювання, не ведуть до зниження національної безпеки, обмеження прав і законних інтересів інших осіб [27, с. 45].

У Рішенні № 18-рп/2004 від 01.12.2004 р. Конституційний суд України визначив основні ознаки охоронюваного законом інтересу як правового феномену, який:

1) виходить за межі змісту суб'єктивного права;

2) $є$ самостійним об'єктом судового захисту та інших засобів правової охорони;

3) має на меті задоволення усвідомлених індивідуальних і колективних потреб;

4) не може суперечити Конституції ій законам України, суспільним інтересам, загальновизнаним принципам права;

5) означає прагнення (не юридичну можливість) до користування в межах правового регулювання конкретним матеріальним та/або нематеріальним благом;

6) розглядається як простий легітимний дозвіл, тобто такий, що не заборонений законом [28].

Із цього випливає, що охоронюваний законом екологічний інтерес $€$ самостійним об'єктом правової охорони. Водночас, на відміну від екологічних прав, захист яких будемо обґрунтувати саме невиконанням чи неналежним виконанням кореспондуючого обов'язку, охорону екологічного інтересу як простого легітимного дозволу «дозволено все, що не заборонено законом» забезпечуватиме весь спектр еколого-правового механізму регулювання суспільних відносин, оскільки «межі законного інтересу випливають із сукупності правових норм, чинних правових принципів» [29, с. 11].

Висновки. Отже, правова природа інтересів у механізмі еколого-правового конфлікту $\epsilon$ різною. На початковому етапі виникнення конфлікту інтерес $\epsilon$ об'єктивною категорією та формою вираження потреби в екологічно безпечному середовищі існування соціуму. Оскільки еколого-правовий конфлікт $\epsilon$ соціальним протиріччям, то інтерес повинен бути усвідомленим суб'єктом соціальної взаємодії, а тому набуває ознак суб'єктивного характеру. Й нарешті, у процесі узгодження інтересів сторін конфлікту інтерес отримує правове опосередкування через суб'єктивні права та законні інтереси. Такий підхід дає можливість координувати та «примирити» існуючі наукові концепції щодо інтересу, правового інтересу та інтересу в екологічному праві.

\section{Література}

1. Лазор О.Я. Конфлікти між екологією та економікою: пошук рішень. Наук. вісник: Лісівницькі дослідження в Україні. 36. наук.-техн. пр. Львів : УкрДЛтУ, 2002. Вип. 12.4. С. 308-317.

2. Про охорону природного довкілля : Закон України від 25.06.1991 р. № 1264-XII. URL: https: / /zakon.rada.gov.ua/laws/show/1264-12\#Text (дата звернення: 12.08.2020).

3. Про основні засади (стратегію) державної екологічної політики України на період до 2030 року : Закон України від 28.02.2019 р. № 2697-VIII. URL: https://zakon.rada.gov.ua/laws/ show/2697-19?find=1\&text=інтерес\#Text (дата звернення: 12.08.2020).

4. Самбор М.А. Інтерес у праві: загальнотеоретичні аспекти розуміння та реалізації : автореф. дис. ... канд. юрид. наук. Київ, 2010. 20 с.

5. Солдатенко С.В. Правовий інтерес: загальнотеоретична характеристика : автореф. дис. ... канд. юрид. наук. Запоріжжя, 2014. 20 с.

6. Попов В.К. Право и материальные интересы в межхозяйственной кооперации: монография. Харьков : Вища шк. Изд-во при Харьк. ун-те, 1983. 169 с.

7. Гетьманцев Д.О. Фінансово-правове зобов'язання як окрема категорія фінансового права: монографія. Київ : Юрінком Інтер, 2001. 368 с.

8. Анісімова Г.В. Теоретичні засади розвитку екологічного законодавства в контексті природно-правової доктрини : монографія. Харків : Право, 2019. 672 c.

9. Балюк Г.І. Охоронюваний законом інтерес у структурі еколого-правового статусу людини і громадянина. Еколого-правовий статус людини і громадянина: ретроспективний та перспективний погляди: зб. матеріалів міжнародної науково-практичної конференції (м. Київ, 31 травня 2019 р.) / за заг. ред. М.В. Краснової, Т.О. Коваленко. Чернівці : Кондратьєв А.В., 2019. С. 9-13.

10. Мороз Г.В. Категорія «інтерес» із позицій еколого-правового підходу. Вчені записки ТНУ імені В.І. Вернадського. Серія: юридичні науки. 2020. Том 31 (70) Ч. 2. № 2. С. 10-14. 
11. Павлова О.В. Правові засади формування екологічної держави за участю громадськості : дис. ... канд. юрид. наук. Харків, 2017. 222 с.

12. Петров В.В. Правовая охрана природы в СССР. M., 1984. 384 C.

13. Шахов В.С. Екологічні інтереси і права людини. Правова держава Україна: проблеми, перспективи розвитку : короткі тези допов. та наук. повідом. республ. наук.-практ. конфер., 9-11 листоп. 1995 р. Харків : Нац. юрид. акад. України ім. Я. Мудрого, 1995. С. 214 - 215.

14. Мороз Г.В. Суть та зміст категорії екологічного інтересу. Актуальні проблеми політики : зб. наук. пр. / редкол. : С.В. Ківалов (голов. ред.), Л.І. Кормич (заст. голов. ред.), Ю.П. Аленін [та ін.] ; МОН України, ОНЮА. Одеса : Фенікс, 2009. Вип. 38. С. 201-207.

15. Мирошниченко А.И. Правовой механизм защиты экологического интереса: теоретикоправовой анализ : автореф. дис. ... канд. юрид. наук. Ростов на Дону, 2011. 26 с.

16. Парфьонов І.І. Суть та природа поняття «екологічний інтерес» в системі державного регулювання регіонального розвитку. Актуальні проблеми державного управління : зб. наук. пр. / Нац. акад. держ. упр. при Президентові України, Одес. регіон. ін-т держ. упр. О., 2013. Вип. 1(53). С. 116-120.

17. Васильева М.И. Проблемы защиты общественного интереса в экологическом праве. Государство и право. 1999. № 8. С. 49-62.

18. Соколова А.А. Механизм согласования интересов в процессе формирования права. Право и демократия : сб. науч. тр. / Редкол.: В.Н. Бибило (отв. ред.) и др. Мн. : БГУ, 2003. Вып 14. URL: https: / / elib.bsu.by/bitstream/123456789/20957/1/4 соколова.pdf (дата звернення: 10.08.2020).

19. Іванов В.М., Іванова О.В. Юридична конфліктологія : навч. посіб. для студ. вищ. навч. закл. Київ : МАУП, 2004. 224 с.

20. Дубовик О.Л. Экологическое право и экологические конфликты. Право и политика. 2006. № 5. С. 116-136.
21. Анісімова Г.В. Здійснення громадянами екологічних прав : автореф дис. ... канд. юрид. наук. Харків, 1996. 19 с.

22. Кобецька Н.Р. Взаємодія та відображення інтересів у екологічному праві України. Держава $i$ право: Збірник наукових праць. Юридичні і політичні науки. Київ : Ін-т держави і права ім. В.М. Корецького НАН України, 2007. Вип. 36. С. 403-408.

23. Бобровник С.В. Компроміс і конфлікт у праві : теоретико-методологічне дослідження : автореф. дис. ... д-ра юрид. наук. Київ, 2013.

24. Ленгер Я.І. Конфлікт та колізія як різновид протиріччя у праві. Електронне фахове видання. Порівняльно-аналітичне право. № 6. 2016. С. 59-61.

25. Жорнокуй Ю.М. Цивільно-правова природа корпоративних конфліктів в акціонерних товариствах : дис. д-ра юрид. наук. Харків, 2016. 476 с.

26. Васильєва В.А. Цивільно-правове регулювання діяльності з надання посередницьких послуг : монографія. Івано-Франківськ : ВДВ ЦІТ Прик. нац. ун-ту, 2006. 345 с.

27. Васильева М.И. О соотношении интереса и субъективного права в экологических правоотношениях. Экологическое право. 2012. № 4. С. 39-47.

28. Рішення Конституційного Суду України у справі за конституційним поданням 50 народних депутатів України щодо офіційного тлумачення окремих положень частини першої статті 4 Цивільного процесуального кодексу України (справа про охоронюваний законом інтерес) №18-рп/2004 від 01.12.2004 p. URL: https://zakon.rada.gov.ua/laws/ show/v018p710-04 (дата звернення: 12.08.2020р.)

29. Витрук Н.В. Правовой статус личности в СССР. M., 1985.

Яремак 3. В., кандидат юридичних наук, доцент, доцент кафедри трудового, екологічного та аграрного права

Прикарпатського національного університету імені Василя Стефаника 